\title{
EFEK SISA ASAM HUMAT DARI KOMPOS JERAMI PADI DAN PENGELOLAAN AIR DALAM MENGURANGI KERACUNAN BESI (FE) TANAH SAWAH BUKAAN BARU TERHADAP PRODUKSI PADI
}

\author{
Ruhaimah, Asmar, M.Harianti \\ J urusan Tanah F akultas Pertanian U nand Padang
}

\begin{abstract}
Fe toxicity on recent ricefield has been common problem in ricefield management to increase rice productivity. Adding organic matter like humic acid from any source (such as hay residue compost) and water management (intermitten flooding and continue flooding) can reduce $\mathrm{Fe}$ toxicity and it will be able to increase rice yield in one plant season. But how about in second plant season, this research will found effect of adding humic acid from hay compost residue and water management. The objective of this research was to study the interaction of hay compost humic acid residue effect and water management on Fe abundant and nutrient uptake and rice yield in recent ricefield. This research has done by split-split plot design $2 \times 4$. The main plot which was treatment of water management were permanent flooding and intermitten (P1 and P2). And the split plot which was humic acid treatments were $A 0=0 \mathrm{ppm}$ ( $0 \mathrm{Kg}$ humic acid /Acre), $\mathrm{A} 1=200 \mathrm{ppm}$ ( $400 \mathrm{Kg}$ humic acid/A), A2=400 ppm ( $800 \mathrm{Kg}$ humic acid/A), A3 $=600 \mathrm{ppm}(1200 \mathrm{Kg}$ humic acid /A). Data analysed by statistical methode, if the treatments were significant to be continued by Duncan $05 \%$ analysis. The result has obtained of this research which was Eh value of soil in flooding and intermitten was decrease in every week because treatment of humic acid in first season. The content of $\mathrm{Fe}^{2+}$ in soil was increase in every week until the $8^{\text {th }}$ week. Value of soil $\mathrm{pH}$ until $8^{\text {th }}$ week flooding was increase, and caused $\mathrm{P}$ available and $\mathrm{P}$ potencial were increase too. Plant growth and yield of rice in second season not better than first season, and for intermitten flooding caused better plant growth and yield of rice.
\end{abstract}

Keyword : F e Toxicity, H umic A cid, water management, Recent Ricefield

\section{PENDAHULUAN}

Semakin berkurangnya areal lahan pertanian produktif akibat dari pesatnya alih fungsi lahan untuk berbagai keperluan non pertanian seperti perumahan, industri dan prasarana jalan atau lain-lainnya menyebabkan pembangunan pertanian, khususnya dalam mempertahankan swasembada beras semakin mendapat tantangan yang berat dan komplek. Penurunan luas lahan akibat alih fungsi lahan sawah produktif (terutama terjadi di pulau Jawa dan Bali) diperkirakan mencapai 35-50 ribu ha/tahun (Noor,1996). Penyusutan luas lahan sawah ini lebih luas dibandingkan dengan perluasan lahan sawah baru.

Lahan yang tersedia untuk dijadikan sawah baru, sebagian adalah lahan marginal. Pemerintah juga mengupayakan untuk memfungsikan lahan-lahan marginal tersebut seperti lahan kering marginal dan lahan gambut menjadi sawah. Penyebaran lahan kering marginal paling luas di Indonesia yaitu mencapai $\pm 56 \%$ dari lahan yang ada. Jenis tanah yang dominan adalah Ultisol dan Oxisol atau disebut Podsolik Merah Kuning (Noor, 1996).

Salah satu daerah yang dijadikan proyek pencetakan sawah baru adalah Sumatera Barat. Daerah utama yang dijangkau oleh proyek ini adalah Kabupaten Dharmasraya yaitu seluas 3,907 ha. Dari laporan Departemen Pemukiman dan Prasarana Wilayah Proyek Irigasi Sumatera Barat (2001), bahwa tanah-tanah pada sawah bukan baru tersebut didominasi oleh tanah mineral masam seperti Ultisol dan Oxisol serta Inceptisol.

Menurut Taher (1990), sawah bukaan baru selalu dihadapkan kepada 
permasalahan rendahnya produktifitas lahan diawal pemanfaatan. Permasalahan ini makin berat pada tanah-tanah mineral masam, seperti Ultisol dan Oxisol. Hal ini terjadi akibat konversi tanah mineral masam menjadi sawah akan meningkatkan kelarutan besi $(\mathrm{Fe})$ dan mangan $(\mathrm{Mn})$ yang merupakan logam-logam berat meracun bagi tanaman padi.

Ponnamperuma (1977, Breemen dan Moorman, 1978 serta Ottow, 1982, dalam Taher, 1990) menyatakan adapun faktor yang menyebabkan keracunan $\mathrm{Fe}$ yaitu $\mathrm{pH}$ rendah, kadar $\mathrm{Fe}$ larut yang tinggi dan kahat hara terutama fosfor $(\mathrm{P})$, kalium $(\mathrm{K})$, kalsium (Ca) dan seng ( $\mathrm{Zn}$ ) atau kombinasi dari faktor tersebut. Ponnamperuma (1972 dalam Yusuf, Djakamihardja, Satari, Djakasutami, 1990) menemukan bahwa kombinasi dari tingginya kelarutan $\mathrm{Fe}$ dengan $\mathrm{pH}$ rendah dapat menimbulkan keracunan Fe pada tanaman padi.

Sanchez (1993) menemukan bahwa penggenangan pada tanah sawah baru dibuka akan menyebabkan tereduksinya $\mathrm{Fe}$ dalam bentuk ferri $\left(\mathrm{Fe}^{3+}\right)$ menjadi ferro $\left(\mathrm{Fe}^{2+}\right)$ sehingga $\mathrm{Fe}^{2+}$ menjadi lebih mudah larut. Ia melanjutkan, puncak kadar senyawa $\mathrm{Fe}$ dapat ditukar atau $\mathrm{Fe}$ larutan tanah biasanya terjadi pada bulan pertama setelah penggenangan dan diikuti penurunan yang berangsur-angsur dimana intensitas puncak ini sangat beragam tergantung pada sifat tanah. Hasil penelitian Sari (2005) diperoleh kandungan Fe yang dapat ditukar sebelum penggenangan pada Ultisol mencapai 60,49 ppm dan setelah penggenangan selama 6 minggu kandungan Fe meningkat menjadi $1600 \mathrm{ppm}$. Shancez (1993) menambahkan bahwa peningkatan $\mathrm{Fe}^{2+}$ pada Ultisol dan Oxisol dapat mencapai 350 ppm yang menyebabkan terjadinya keracunan $\mathrm{Fe}$.

Keracunan Fe menyebabkan pertumbuhan tanaman padi terhambat, kerdil dan pembentukan anakan terbatas akibat terbatasnya perkembangan akar, serta dapat memberikan hasil padi $\pm 52-75 \%$ lebih rendah dibandingkan tanaman sehat (Burbey, Hamzah, dan Zaini, 1990). Menurut Lu Tian-ren (1985 dalam Yusuf et al, 1990), batas kritis Fe dalam larutan tanah untuk tanaman padi berkisar antara 50-100 ppm.

Oleh sebab itu diperlukan suatu teknologi yang dapat mengurangi kelarutan $\mathrm{Fe}^{2+}$ agar tidak meracun bagi tanaman. Pengendalian keracunan $\mathrm{Fe}$ melalui perbaikan lingkungan pertumbuhan dapat dilakukan dengan pengelolaan air dan pemberian bahan organik. Pengelolaan air dengan cara pengairan terputus-putus dapat mengatasi keracunan $\mathrm{Fe}$ terhadap padi. Burbey et al, (1990) menyatakan bahwa pengeringan lahan selama seminggu dan penggenangan selama 1-2 minggu mulai saat tanam mampu mengatasi keracunan $\mathrm{Fe}$.

Bahan organik yang diberikan menghasilkan asam-asam organik dan pada tahap dekomposisi lanjut menghasilkan asam humat dan asam fulvat yang mempunyai gugus fungsional karboksil dan fenolik yang dapat mengikat logam seperti Fe membentuk senyawa metal organo komplek (khelat). Pengikatan ini akan mengurangi aktivitas logam $\mathrm{Fe}$, karena berkurangnya kelarutan $\mathrm{Fe}$ dalam tanah sehingga mengurangi penyerapan $\mathrm{Fe}$ oleh tanaman (Ahmad, 1990). Bahan organik yang dapat dimanfaatkan salah satunya dalam bentuk kompos jerami padi. Pemanfaatan limbah organik jerami padi belum dimanfaatkan secara maksimal. Tanaman padi dimanfaatkan hanya pada bulir padinya yaitu sebagai penghasil beras. Bagian-bagian padi yang lain (jerami) sebagai sisa panen sedikit sekali dimanfaatkan oleh manusia (Kurniawan dan Rima, 1997).

Biomassa jerami padi mengandung beberapa unsur hara seperti senyawa nitrogen $(\mathrm{N})$ dan karbon $(\mathrm{C})$ yang berfungsi sebagai substrat metabolisme mikroba tanah, termasuk gula, pati, selulosa, hemiselulosa, pektin, lignin, lemak dan protein. Senyawa tersebut menduduki $40 \%$ (sebagai C) berat kering jerami (Susanto, 2002). Hasil penguraian dari kompos jerami padi akan menghasilkan asam-asam organik seperti asam humat, asam fulvat dan fraksi humin. Dengan melihat sifat-sifat kimia fraksi humat asal kompos jerami padi, maka fraksi humat mempunyai potensi besar dalam memperbaiki dan meningkatkan 
kesuburan tanah marjinal seperti Ultisol dan Oxisol (Kurniawan dan Rima, 1997).

Herviyanti, Prasetyo, Alif, dan Agita (2005) melaporkan bahwa pemberian asam humat dari kompos jerami padi yang semakin meningkat pada penanaman pertama mampu mengurangi kandungan $\mathrm{Fe}$ tanah yang semakin besar. Kemampuan asam humat dari kompos jerami padi mengurangi kandungan Fe pada takaran 400 ppm pada minggu ke-6 adalah 643,95 ppm. Disamping itu penggenangan yang diselingi pengeringan dapat mengurangi kadar $\mathrm{Fe}^{2+}$ tanah sawah bukaan baru. Semakin lama penggenangan dan pengeringan maka tingkat kelarutan $\mathrm{Fe}$ semakin rendah. Penggenangan dan pengeringan selama 2 dan 3 minggu dapat mengurangi kelarutan Fe yang relatif sama yaitu sebesar $1300 \mathrm{ppm}$.

Efek sisa yang ditimbulkan oleh asam humat akan terlihat setelah penanaman berikutnya. Namun, sejauh ini penelitian yang telah dilaporkan hanya tentang mekanisme reaksi dan potensi asam humat dalam menurunkan kandungan $\mathrm{Fe}^{2+}$ pada tanah sawah, sedangkan berapa lama efek sisa asam humat mampu mengurangi $\mathrm{Fe}^{2+}$ belum diketahui. Oleh karena itu, untuk mengetahui hal tersebut maka perlu dilakukan penelitian lanjutan.

Berdasarkan latar belakang di atas, maka penulis tertarik melakukan penelitian dengan judul : Efek sisa asam humat dari kompos jerami padi dan pengelolaan air dalam mengurangi keracunan besi $(\mathrm{Fe})$ tanah sawah bukaan baru terhadap produksi padi. Tujuan dari penelitian ini adalah : (1) Mempelajari interaksi antara efek sisa asam humat dan pengelolaan air terhadap kandungan Fe tanah sawah dan serapan hara serta produksi tanaman padi. (2) Mempelajari efek sisa asam humat terhadap kandungan Fe tanah sawah dan serapan hara serta produksi tanaman padi.

Mempelajari pengaruh utama pengelolaan air terhadap kandungan Fe tanah sawah dan serapan hara serta produksi tanaman padi.

\section{METODOLOGI PENELITIAN}

Penelitian ini dilaksanakan di Rumah kaca Fakultas Pertanian Universitas
Andalas Padang. Analisis tanah dan tanaman dilakukan di Laboratorium Jurusan Tanah Fakultas Pertanian Universitas Andalas Padang. Penelitian ini berlangsung dari bulan Maret sampai Agustus 2007. Penelitian ini menggunakan Ultisol yang terdapat pada lahan sawah bukaan baru di kecamatan Koto Baru, Sitiung, Kabupaten Dharmasraya, Sumatera Barat, yang telah diberi perlakuan asam humat dari kompos jerami padi dengan berbagai perlakuan dosis pada penanaman pertama. Sebagai tanaman indikator digunakan tanaman padi varietas Cisokan. Untuk pemupukan digunakan Urea, SP-36, dan KCl. Insektisida yang digunakan adalah Dharmabas dan fungisida yang digunakan adalah Butacanol.

Rancangan percobaan yang digunakan adalah Rancangan Faktorial 2 x 4 dalam petak terbagi terdiri dari 2 perlakuan pengelolaan air sebagai petak utama, 4 perlakuan dosis asam humat dari kompos jerami padi sebagai anak petak dengan 3 ulangan. Petak utama adalah pengelolaan air, yang terdiri atas: $\mathrm{P}_{1}$ : Penggenangan terus menerus, $\mathrm{P}_{2}$ : Penggenangan 2 minggu dan pengeringan 2 minggu bergantian. Anak petak adalah perlakuan dosis asam humat yang telah dilakukan adalah sebagai berikut : $\mathrm{A}_{0}=0 \mathrm{ppm}$ setara dengan $0 \mathrm{Kg}$ asam humat $/ \mathrm{Ha}, \quad \mathrm{A}_{1}=200 \mathrm{ppm}$ setara dengan $400 \mathrm{Kg}$ asam humat $/ \mathrm{Ha}, \mathrm{A}_{2}=400 \mathrm{ppm}$ setara dengan $800 \mathrm{Kg}$ asam humat $/ \mathrm{Ha}, \mathrm{A}_{3}=$ $600 \mathrm{ppm}$ setara dengan $1200 \mathrm{Kg}$ asam humat/Ha. Data yang diperoleh dianalisis secara statistik dengan menggunakan uji Fisher $5 \%$ dan apabila berbeda nyata dilakukan uji lanjut dengan uji DNMRT taraf $5 \%$ (Gasperz, 1995).

Pelaksanaan penelitian meliputi : Persiapan tanah dan penggenangan, tanah yang digunakan untuk penanaman adalah Ultisol yang telah diberi perlakuan dosis asam humat dari kompos jerami padi dan pengelolaan air pada penanaman pertama sebanyak 24 pot. Berat tanah setiap pot dianggap sama dengan percobaan pertama yaitu $10 \mathrm{~kg} /$ pot. Setelah panen pada penanaman pertama, tanah dibersihkan dari sisa-sisa akar tanaman dan dilakukan pengambilan contoh tanah untuk analisis tanah setelah panen pertama. Persemaian 
benih padi, persemaian padi dilakukan dengan cara sebagai berikut: benih padi disemaikan pada media persemaian ( seedbed ) berisi Inceptisol sebanyak $5 \mathrm{~kg}$, pupuk Urea dan $\mathrm{KCl}$ masing-masing $3 \mathrm{~g}$ dan pupuk SP-36 sebanyak 4,5 g (dosis pupuk pada persemaian berdasarkan rekomendasi pemupukan padi varietas Cisokan).

Pemupukan dan penanaman padi, pemberian pupuk didasarkan pada perhitungan pupuk tiap pot pada jarak tanam $25 \times 25 \mathrm{~cm}$ (dengan populasi tanaman $160.000 \mathrm{~m}^{2}$ ). Jumlah pupuk yang diberikan adalah pupuk $\mathrm{N}$ sebanyak $300 \mathrm{~kg}$ urea/ha (setara $1,875 \mathrm{~g} /$ pot), pupuk P sebanyak 300 kg SP-36/ha (setara 1,875 g/pot) dan pupuk $\mathrm{K}$ sebanyak $100 \mathrm{~kg} \mathrm{KCl} / \mathrm{ha}$ (setara 0,625 $\mathrm{g} / \mathrm{pot}$ ). Pupuk Urea dan $\mathrm{KCl}$ diberikan 1/3 bagian pada saat sebelum tanam, $1 / 3$ bagian pada saat tanaman berumur 4 MST (minggu setelah tanam) dan $1 / 3$ bagian pada saat tanaman berumur 8 MST. Untuk setiap pot akan ditanami 5 bibit padi varietas Cisokan berumur 21 hari.

Pemeliharaan meliputi : untuk penggenangan secara terus menerus ketinggian air dipertahankan setinggi $5 \mathrm{~cm}$ dengan cara menambah air setiap terjadi penurunan permukaan air. Sedangkan untuk perlakukan penggenangan 2 minggu dan pengeringan 2 minggu, tinggi air dipertahankan setinggi $5 \mathrm{~cm}$ selama penggenangan. Pencegahan hama dan penyakit tanaman dilakukan pada umur tanaman padi 4 minggu dengan cara penyemprotan yang menggunakan insektisida Dharmabas konsentrasi 5-10 $\mathrm{cc} / \mathrm{L}$ dan untuk fungisida digunakan Butacanol konsentrasi 2-5 cc/L. Masingmasing penyemprotan dilakukan seminggu sekali.

Pemanenan untuk analisis kadar hara tanaman dilakukan pada saat tanaman padi mencapai fase pertumbuhan vegetatif maksimum (umur 8 minggu), dimana pemanenan dilakukan dengan mengambil 57 helai daun tanaman per pot. Daun yang diambil adalah daun keempat dari pucuk tanaman. Selanjutnya pemanenan dilakukan pada saat tanaman berumur 115 hari yang ditunjukkan dengan ciri daun padi telah menguning, bulir $85 \%$ telah masak dan biji bila ditekan terasa padat. Panen dilakukan dengan pengambilan keseluruhan bagian tanaman, dengan cara dipotong kira-kira 2 $\mathrm{cm}$ dari permukaan tanah.

Analisis tanah yang telah dilakukan meliputi: 1) Analisis tanah setelah panen pertama, dilakukan di Laboratorium meliputi : pengukuran P-tersedia dengan metoda Bray II, P-potensial dengan metoda ekstraksi $25 \% \mathrm{HCl}$, dan $\mathrm{Fe}^{2+}$ dengan metoda ekstraksi $1 \mathrm{M}$ Na-asetat $\mathrm{pH} 2,8$. Untuk analisis tanah setelah panen pertama dilakukan setelah tanah tersebut dibersihkan dari sisa panen pertama. Tanah diambil sebanyak $\pm 14 \mathrm{~g}$ dengan cara menekan tabung sentrifus dengan perlahan dan hatihati dari permukaan tanah dipot agar perakaran dari tanaman padi tidak terganggu. Untuk pH dan Eh langsung diukur pada pot dengan menggunakan alat $\mathrm{pH}$ meter. Analisis tanah selama tanam, metoda dan prosedur analisis tanah dilakukan seperti analisis tanah setelah panen pertama, meliputi: analisis $\mathrm{Fe}^{2+}$, P-potensial, $\mathrm{P}$ tersedia, $\mathrm{pH}$ dan Eh. Pengambilan contoh tanah dilakukan pada minggu ke-4 dan ke- 8 (pada titik krusial pertumbuhan vegetatif tanaman) setelah tanam.

Pengamatan tanaman telah dilakukan adalah: a) Tinggi tanaman $(\mathrm{cm})$ pengamatan tinggi tanaman dilakukan dengan mengukur tanaman mulai dari tiang standar. b) Jumlah anakan total (batang) jumlah anakan total dihitung pada saat pertumbuhan vegetatif maksimum tanaman. Pengamatan dilakukan satu kali yaitu pada saat awal munculnya malai. c) Jumlah anakan produktif (batang), pengamatan terhadap jumlah anakan produktif dilakukan dengan menghitung jumlah anakan yang menghasilkan malai pada setiap anakan per pot. Malai yang dihitung yaitu malai yang menghasilkan gabah bernas. Pengamatan dilakukan satu kali yaitu menjelang panen. d) Berat total gabah kering (gram), gabah yang telah diperoleh dengan perontokkan, ditimbang berat basahnya kemudian dikeringkan dengan oven pada suhu $60^{\circ} \mathrm{C}$ selama 48 jam sampai bobotnya tetap, kemudian ditimbang bobot total gabah kering. e) Bobot 1000 butir gabah (gram), 
gabah bernas yang diperoleh dihitung bobot 1000 butirnya dengan rumus sebagai berikut:

$$
\begin{gathered}
\text { Bobot } 1000 \text { butir }(\mathrm{g})=\text { Bobot } 10 \text { butir } \\
\text { gabah bernas }(\mathrm{g}) \times 100
\end{gathered}
$$

f) Berat kering jerami (gram), bobot kering jerami diperoleh dengan cara jerami dikeringkan dalam oven pada suhu $60^{\circ} \mathrm{C}$ selama \pm 48 jam sampai bobotnya tetap, lalu ditimbang bobot kering jerami padi. Seluruh data hasil pengamatan tanaman diolah secara statistik.

Analisis kadar hara tanaman yang dilaksanakan meliputi analisis $\mathrm{Fe}^{2+}$ dengan metoda ekstraksi $1,5 \% \quad 1-1$ orthophenanthroline, dan P tanaman dengan metoda Destruksi basah. Sampel tanaman diambil dengan cara memetik 5-7 helai daun ke-4 dihitung dari pucuk tanaman pada saat tanaman padi mencapai fase pertumbuhan vegetatif maksimum. Data hasil analisis tersebut diolah secara statistik.

\section{HASIL DAN PEMBAHASAN}

Nilai Eh tanah sawah bukaan baru selama 8 minggu penggenangan

Secara umum nilai Eh tanah pada penggenangan terus menerus dan selang seling mengalami penurunan pada setiap minggunya. Penurunan nilai Eh juga terjadi seiring dengan meningkatnya kandungan sisa asam humat di dalam tanah yang telah diberikan dari penanaman pertama.

Penurunan nilai Eh hingga minggu ke 8 penggenangan semakin lama semakin besar yaitu berkisar $82.30 \mathrm{mV}-118.76 \mathrm{mV}$ untuk penggenangan terus menerus dan $133.66 \mathrm{mV}$ - $142.16 \mathrm{mV}$ penggenangan selang seling. Hal ini dikarenakan telah terjadi proses reduksi yang lebih sempurna di dalam tanah, dimana terjadinya peralihan dekomposisi bahan organik tanah dari kondisi aerob menjadi kondisi anaerob oleh mikroorganisme tanah. Dalam keadaan tergenang, laju difusi oksigen udara melalui lapisan air 10 ribu kali lebih lambat daripada melalui pori yang berisi udara. Awal penggenangan, mikroba aerob dengan cepat akan menghabiskan udara yang tersisa dan menjadi tidak aktif lagi atau mati. Mikroba fakultatif anaerob dan obligat aerob kemudian mengambil alih dekomposisi bahan organik tanah dengan menggunakan komponen tanah teroksidasi atau hasil penguraian bahan organik sebagai penerima elektron dalam pernafasan (Sanchez, 1993;Kyuma, (2004 dalam Prasetyo et al, 2004)).

Bila dibandingkan dengan Eh pada penanaman pertama, nilai Eh pada penanaman ke dua ini jauh lebih besar. Pada penanaman pertama nilai Eh berkisar antara 15 - $25 \mathrm{mV}$ untuk tanah yang digenangi terus menerus dan $40-70 \mathrm{mV}$ untuk tanah yang digenangi selang seling (Herviyanti, 2007), sedangkan nilai Eh pada penanaman kedua masing-masingnya berkisar antara 82.30-118.76 mV dan 133.66-142.16 mV. Perbedaan nilai Eh yang cukup besar ini diduga karena tanah pada penanaman kedua telah lama dikeringkan sebelum ditanam kembali. Pada saat kering, oksigen akan masuk ke dalam tanah dan tanah berada pada kondisi oksidasi, dimana jumlah elektron akan menurun dan konsentrasi oksigen meningkat. Walaupun nilai Eh tanah pada penanaman kedua lebih besar dari nilai Eh pada penanaman pertama, namun sisa asam humat ternyata masih mampu menurunkan nilai Eh tanah hingga penanaman kedua ini.

Kadar $\mathrm{Fe}^{+2}$ dalam larutan tanah selama 8 minggu penggenangan

Kadar $\mathrm{Fe}^{+2}$ tanah pada masing-masing yang mengandung sisa asam humat dengan takaran 200, 400, dan 600 ppm mengalami peningkatan dari awal minggu penggenangan sampai minggu ke 8. Namun, peningkatannya semakin menurun seiring dengan meningkatnya takaran asam humat yang diberikan pada penanaman pertama. Hingga minggu ke 8 penggenangan, peningkatan kadar $\mathrm{Fe}^{+2}$ untuk tanah yang digenangi terus menerus akibat sisa asam humat berturut-turut: $144.25,78.19$ dan $53.57 \mathrm{ppm}$, sedangkan untuk tanah yang digenangi selang seling yaitu: 23.36, 22.49 dan $20.40 \mathrm{ppm}$. Kadar Fe yang semakin menurun dengan bertambahnya takaran asam humat ini karena semakin tinggi 
takaran asam humat, maka sisa asam humat yang ada didalam tanah juga semakin meningkat. Peningkatan kandungan asam humat didalam tanah akan memperbanyak pengikatan $\mathrm{Fe}$ dalam bentuk reaksi khelat dan komplek, sehingga kadar $\mathrm{Fe}$ dalam larutan tanah akan semakin menurun.

Kadar $\mathrm{Fe}^{+2}$ yang berkisar antara 68.56 - 316.34 ppm pada penanaman kedua ini masih berada pada konsentrasi yang meracun bagi tanaman. Tanaka (1966, dalam Herviyanti 2007) mengemukakan bahwa Fe larutan tanah yang meracun bagi tanaman berkisar antara $10-1000$ ppm. Walaupun demikian, kadar $\mathrm{Fe}^{+2}$ pada penanaman kedua ini jauh lebih rendah dari pada kadar $\mathrm{Fe}^{+2}$ pada penanaman pertama. Kadar $\mathrm{Fe}^{+2}$ pada penanaman pertama mencapai 900 - 1000 ppm. Pada penanaman kedua kadar $\mathrm{Fe}^{+2}$ dapat ditekan hingga 68.56-316.34 ppm. Hal ini menunjukkan bahwa sisa asam humat masih mampu mengurangi kadar $\mathrm{Fe}^{+2}$ tanah hingga penanaman kedua, namun kemampuannya mengalami penurunan dari penanaman pertama.

Nilai pH tanah selama 8 minggu penggenangan

Jumlah kenaikan $\mathrm{pH}$ tanah tanpa asam humat lebih rendah dari pada kenaikan $\mathrm{pH}$ untuk tanah dengan kandungan sisa asam humat dari awal minggu penggenangan sampai minggu ke 8 penggenangan. Kenaikan $\mathrm{pH}$ tanah untuk penggenangan terus menerus tanpa asam humat hanya 0.44 unit, dan untuk tanah yang digenangi selang seling sebesar 0.65 unit. Rendahnya nilai $\mathrm{pH}$ pada tanah tanpa asam humat ini dikarenakan reduksi $\mathrm{Fe}^{+3}$ menjadi $\mathrm{Fe}^{+2}$ yang melepaskan $\mathrm{OH}^{-}$berjalan lambat. Lambatnya reduksi disebabkan oleh tidak adanya sumbangan elektron yang berasal sisa asam humat, sehingga jumlah elektron yang ada di dalam tanah relatif kecil. Rendahnya jumlah elektron ini terlihat dari nilai Eh yang tinggi, yaitu berkisar antara $118.76 \mathrm{mV}$ dan $142.16 \mathrm{mV}$. Sanchez (1993) mengemukakan bahwa secara umum penggenangan dapat meningkatkan $\mathrm{pH}$ tanah masam dan menurunkan $\mathrm{pH}$ tanah basa. Akan tetapi, peningkatan $\mathrm{pH}$ pada tanah masam tergantung kepada besar kecilnya jumlah $\mathrm{OH}^{-}$yang dilepaskan saat reduksi $\mathrm{Fe}^{+3}$ menjadi $\mathrm{Fe}^{+2}$.

Bila dibandingkan dengan kenaikan $\mathrm{pH}$ pada penanaman pertama, kenaikan $\mathrm{pH}$ pada penanaman kedua relatif lebih rendah. Pada penanaman pertama nilai $\mathrm{pH}$ dapat mencapai 6.50 - 7.30 untuk tanah yang digenangi terus menerus dan $6.20-6.80$ untuk tanah yang digenangi selang seling (Herviyanti, 2007). pH tanah pada penanaman kedua hanya berkisar antara 5.42 - 6.27 untuk tanah yang digenangi terus menerus dan $5.00-5.12$ untuk tanah yang digenangi selang seling. Hal ini disebabkan oleh kecepatan reduksi $\mathrm{Fe}^{+3}$ menjadi $\mathrm{Fe}^{+2}$ lebih lambat pada penanaman kedua. Lambatnya reduksi $\mathrm{Fe}$ ini disebabkan oleh sumbangan elektron yang berasal dari asam humat pada penanaman kedua lebih kecil bila dibandingkan dengan sumbangan elektron dari asam humat pada penanaman pertama. Walaupun demikian, sisa asam humat yang ada di dalam tanah hingga penanaman kedua ini ternyata masih mampu mereduksi $\mathrm{Fe}^{3+}$ menjadi $\mathrm{Fe}^{2+}$ yang mempengaruhi $\mathrm{pH}$ tanah, dengan total kenaikan $\mathrm{pH}$ mencapai 5.59 unit.

Kandungan Pospor - tersedia tanah sawah bukaan baru selama 8 minggu penggenangan

Ketersediaan $\mathrm{P}$ tanah semakin meningkat hingga minggu ke 8 penggenangan. Kenaikan $\mathrm{P}$ ini berkisar antara 5.57 - $12.47 \mathrm{ppm}$ untuk tanah yang digenangi terus menerus dan $5.86-11.37$ ppm untuk tanah yang digenangi selang seling akibat sisa asam humat. Kenaikan kandungan P-tersedia ini lebih besar dari kenaikan $\mathrm{P}$ tersedia pada tanah tanpa asam humat. Tanah yang digenangi terus menerus tanpa asam humat hanya mengalami kenaikan P sebesar 7.76 ppm dan untuk tanah yang digenangi selang seling tanpa asam humat mengalami kenaikan $\mathrm{P}$ sebesar $8.04 \mathrm{ppm}$ pada minggu ke 8 . Rendahnya kenaikan $\mathrm{P}$ pada tanah tanpa asam humat disebabkan oleh tidak adanya kandungan asam humat yang dapat melepaskan ikatan $\mathrm{P}$ 
dari Fe tanah. P yang tersedia pada tanah tanpa asam humat, hanya berasal dari pengaruh penggenangan saja.

Peningkatan kandungan P-tersedia terbesar ditemukan pada tanah dengan sisa asam humat $600 \mathrm{ppm}$, yaitu $12.47 \mathrm{ppm}$ untuk tanah yang digenangi terus menerus dan $11.37 \mathrm{ppm}$ untuk tanah yang digenangi selang seling. Hal ini diasumsikan kandungan sisa asam humat di dalam tanah lebih besar pada takaran tersebut. Semakin besar sisa asam humat dalam tanah, maka gugus fenolik dan hidroksil yang dapat mengikat $\mathrm{Fe}$ juga lebih besar, sehingga $\mathrm{P}$ yang terlepas ke larutan tanah menjadi lebih banyak.

Kandungan P-tersedia pada penanaman kedua ini lebih tinggi dari kandungan P-tersedia tanah pada penanaman pertama. P-tersedia pada penanaman kedua hingga minggu ke 8 penggenangan berkisar antara $7.66-12.47$ ppm untuk semua perlakuan, sedangkan Ptersedia pada penanaman pertama hanya berkisar antara $5.16-8.44 \mathrm{ppm}$. Hal ini dikarenakan kadar $\mathrm{Fe}$ tanah yang dapat mengikat $\mathrm{P}$ pada penanaman kedua ini juga lebih rendah, yaitu berkisar antara 68.56 $316.34 \mathrm{ppm}$. Selain itu, peningkatan takaran pemupukan $\mathrm{P}$ pada penanaman kedua dari $150 \mathrm{~kg} / \mathrm{Ha}$ menjadi $300 \mathrm{~kg} / \mathrm{Ha}$ menyebabkan kandungan P-tersedia tanah pada penanaman kedua ini meningkat.

Kandungan P- Potensial tanah sawah bukaan baru selama 8 minggu penggenangan

P-potensial tanah tanpa perlakuan asam humat lebih tinggi dari P-potensial tanah akibat sisa asam humat dari penanaman pertama. Hingga minggu ke 8 penggenangan, P-potensial tanah tanpa asam humat mencapai $30.95 \mathrm{ppm}$ untuk tanah yang digenangi terus menerus dan 25.21 ppm untuk tanah yang digenangi selang seling. Hal ini dikarenakan pada tanah tanpa asam humat, $\mathrm{P}$ lebih banyak diikat oleh $\mathrm{Fe}$. Kandungan P-potensial tanah mengalami penurunan seiring dengan meningkatnya kandungan asam humat di dalam tanah. Hingga minggu ke 8 penggenangan, kandungan $\mathrm{P}$ potensial tanah untuk masing- masing takaran asam humat 200, 400 dan 600 ppm , yaitu: 21.82, 18.46, dan 13.87 ppm untuk tanah yang digenangi terus menerus dan 18.96, 15.50, dan 11.57 ppm untuk tanah yang digenangi selang seling. P-potensial tanah terendah ditemukan pada tanah akibat efek sisa asam humat dengan takaran 600 ppm, yaitu 13.87 ppm untuk tanah yang digenangi terus menerus dan 11.57 ppm untuk tanah yang digenangi selang seling. Hal ini terjadi diasumsikan pada takaran tersebut sisa asam humat yang ada di dalam tanah berada dalam jumlah yang lebih besar, sehingga gugus karboksil dan fenolik yang dapat melepaskan ikatan $\mathrm{P}$ dari $\mathrm{Fe}$ juga lebih banyak.

\section{Tinggi tanaman $(\mathrm{cm})$}

Pengaruh utama pengelolaan air berbeda nyata terhadap tinggi tanaman padi, sedangkan pengaruh utama sisa asam humat dan pengaruh interaksi sisa asam humat dengan pengelolaan air berbeda tidak nyata terhadap tinggi tanaman. Perlakuan penggenangan terus menerus dan selang seling dapat meningkatkan tinggi tanaman. Secara umum tinggi tanaman pada penggenangan selang seling lebih tinggi $10.89 \mathrm{~cm}$ dibanding penggenangan terus menerus. Hal ini disebabkan ada penggenangan terus menerus tanaman padi tersebut mengalami keracunan besi. Keracunan besi menyebabkan pertumbuhan tanaman terhambat, kerdil dan pembentukan anakan terbatas akibat terbatasnya perkembangan akar (Ismunadji dan Sabe, 1988). Pada perlakuan tanpa asam humat pada tanah yang digenangi selang seling lebih tinggi yaitu $83.28 \mathrm{~cm}$ dibandingkan dengan tanah yang digenangi terus menerus $66.83 \mathrm{~cm}$.

Tinggi tanaman semakin meningkat seiring dengan meningkatnya takaran pemberian asam humat. Secara umum, sisa asam humat dari takaran $200 \mathrm{ppm}$ menjadi 600 ppm dapat meningkatkan tinggi tanaman sebesar $9.76 \mathrm{~cm}$. Hal ini terjadi karena semakin tinggi kandungan asam humat di dalam tanah, maka kemampuannya 
dalam mengurangi kelarutan $\mathrm{Fe}$ tanah semakin meningkat.

Tinggi tanaman tertinggi ditemukan pada sisa asam humat dengan takaran pemberian $600 \mathrm{ppm}$, yaitu $84.37 \mathrm{ppm}$. Akan tetapi, jika dibandingkan pada deskripsi tanaman padi varietas Cisokan, maka tinggi tanaman padi pada penanaman kedua ini lebih rendah. Tinggi tanaman padi pada deskripsi tersebut berkisar antara 90-100 cm. Hal ini terjadi karena pada penanaman kedua ini, tanaman telah mengalami keracunan $\mathrm{Fe}$ (kelarutan $\mathrm{Fe}$ berkisar antara 68.56 - $107.70 \mathrm{ppm})$.

Bila dibandingkan dengan penanaman pertama, tinggi tanaman pada penanaman kedua jauh lebih rendah. Pada penanaman pertama tinggi tanaman untuk penggenangan selang seling $91.04 \mathrm{~cm}$ lebih tinggi dibandingkan dengan penggenangan terus menerus yang hanya $84.88 \mathrm{~cm}$. (Herviyanti, 2007) sedangkan pada penanaman kedua tinggi tanaman hanya $85.35 \mathrm{~cm}$ untuk penggenangan selang seling dan $74.46 \mathrm{~cm}$ untuk penggenangan terus menerus.

Jumlah anakan total dan produktif (batang)

Pengaruh utama pengelolaan air, sisa asam humat dan pengaruh interaksi sisa asam humat dengan pengelolaan air berbeda tidak nyata terhadap jumlah anakan total tanaman. Jumlah anakan total tanaman padi dengan penggenangan terus menerus dan selang seling hingga minggu ke 8 penggenangan semakin meningkat. Peningkatan jumlah anakan total pada penggenangan terus menerus sekitar 1-4 anakan, sedangkan untuk penggenangan selang seling sebesar 1-5 anakan. Pada jumlah anakan produktif, pengaruh utama pengelolaan air, sisa asam humat dan pengaruh interaksi sisa asam humat dengan pengelolaan air berbeda tidak nyata.

Jumlah anakan total pada penanaman kedua ini lebih banyak bila dibandingkan dengan jumlah anakan total pada penanaman pertama. Hal ini menunjukkan bahwa keracunan tanaman terhadap kelarutan $\mathrm{Fe}$ semakin menurun.
Menurunnya kadar kelarutan $\mathrm{Fe}$ pada penanaman kedua ini terlihat dari kadar kelarutan Fe yang berkisar antara 68.56 316.34 ppm, sedangkan kelarutan Fe pada penanaman pertama mencapai 900 - 1000 ppm (Herviyanti, 2007).

Kelarutan $\mathrm{Fe}$ yang tinggi akan menghambat pertumbuhan akar tanaman, sehingga pembentukan anakan akan menjadi terhambat. Yusuf et al, (1990) mengemukakan bahwa kelarutan Fe yang tinggi akan mengendap dipermukaan akar tanaman sehingga dapat menghambat perkembangan akar. Semakin menurunnya kelarutan $\mathrm{Fe}$ pada tanah, maka keracunan tanaman terhadap kelarutan $\mathrm{Fe}$ akan semakin menurun, sehingga pertumbuhan tanaman akan menjadi lebih baik. Peningkatan jumlah anakan produktif pada penanaman kedua ini relatif sama dengan peningkatan jumlah anakan produktif pada penanaman pertama, yaitu berkisar 5 anakan. Hal ini dikarenakan tanaman mengalami keracunan $\mathrm{Fe}^{+2}$ baik pada penanaman pertama, maupun pada penanaman kedua. Keracunan $\mathrm{Fe}^{+2}$ pada penanaman kedua ini sudah mulai terlihat saat tanaman berumur 5 minggu setelah tanam. Keracunan ini terlihat dari warna daun tanaman yang berwarna bercak kecoklat-coklatan.

\section{Kadar Fe tanaman (ppm)}

Kadar Fe tanaman semakin menurun dengan adanya peningkatan kandungan sisa asam humat baik pada penggenangan terus menerus maupun pada penggenangan selang seling. Pada penggenangan terus menerus kadar Fe tanaman semakin menurun dari 37.84 ppm pada takaran 200 ppm asam humat menjadi $27.87 \mathrm{ppm}$ pada takaran 600 ppm asam humat tapi lebih tinggi dari pada penggenangan selang seling yang hanya berkisar 21.94 ppm pada takaran 200 ppm asam humat menjadi $15.84 \mathrm{ppm}$ pada takaran $600 \mathrm{ppm}$. Hal ini membuktikan bahwa semakin tinggi takaran asam humat yang diberikan, maka diasumsikan sisa asam humat yang ada di dalam tanah semakin meningkat, sehingga kemampuannya dalam menurunkan kadar Fe tanaman semakin besar. 
Penurunan kadar $\mathrm{Fe}$ seiring dengan meningkatnya takaran asam humat, juga dipengaruhi oleh semakin menurunnya kadar kelarutan $\mathrm{Fe}$ tanah. Peningkatan takaran asam humat dari $200 \mathrm{ppm}$ menjadi 600 ppm dapat menurunkan kadar kelarutan $\mathrm{Fe}$, hingga kadar Fe terendah berkisar antara 68.56-107.70 ppm. Dengan berkurangnya kelarutan $\mathrm{Fe}$ tanah, maka jumlah $\mathrm{Fe}$ yang diserap oleh tanaman akan semakin menurun, sehingga kadar $\mathrm{Fe}$ tanaman menjadi semakin berkurang.

Hal ini terlihat dari gejala keracunan Fe pada daun tanaman yang berwarna coklat kemerahan. Gejala ini mulai terlihat pada saat tanaman berumur 5 minggu setelah tanam. Marschner (1995 dalam Herviyanti, 2007) mengemukakan bahwa akibat dari keracunan Fe pada tanaman padi adalah produksi dari radikal oksigen yang berlebihan, melebihi kapasitas tanaman untuk mengontrol radikal-radikal ini. Selanjutnya dijelaskan bahwa radikal hidroksil yang terbentuk pada kadar Fe yang tinggi akan menyebabkan auto katalis dari lemak dalam membran sel dan degradasi dari protein yang diperlihatkan dengan adanya bronzing pada daun tanaman.

Kadar Fe tanaman pada penanaman kedua ini lebih rendah dari kadar $\mathrm{Fe}$ tanaman pada penanaman pertama. Pada penanaman pertama kadar $\mathrm{Fe}$ tanaman berkisar antara 78.47 - 249.20 ppm (Herviyanti, 2007) sedangkan pada penanaman kedua hanya berkisar antara 15.84-38.46 ppm. Hal ini karena kelarutan Fe pada penanaman kedua juga lebih rendah, yaitu 68.56 - 316.34 ppm, sedangkan kelarutan $\mathrm{Fe}$ pada penanaman pertama mencapai 900 - 1000 ppm (Herviyanti, 2007). Semakin rendahnya kelarutan $\mathrm{Fe}$ tanah, maka jumlah Fe yang diserap oleh tanaman juga semakin menurun. Hal ini membuktikan bahwa hingga penanaman kedua sisa asam humat ternyata masih mampu mengurangi kadar Fe tanaman yang terlihat dari semakin menurunnya kadar $\mathrm{Fe}$ tanaman pada penanaman kedua.

Berat total gabah kering (g)

Berat kering gabah semakin meningkat seiring dengan meningkatnya takaran pemberian asam humat. Sisa asam humat takaran 400 ppm dapat meningkatkan berat kering gabah sebesar $8 \mathrm{~g}$. Hal ini membuktikan bahwa sisa asam humat yang ada di dalam tanah mampu mengurangi keracunan $\mathrm{Fe}^{2+}$ terhadap tanaman yang dapat menghambat produksi tanaman. Pemberian asam humat dapat menurunkan kadar kelarutan $\mathrm{Fe}$, dimana hingga minggu ke 8 penggenangan kelarutan $\mathrm{Fe}$ hanya berkisar antara 53.57 - 144.25 ppm. Semakin berkurangnya kadar $\mathrm{Fe}^{+2}$ tanah, maka kemampuan tanaman dalam menyerap hara $\mathrm{P}$ yang sangat berperan dalam peningkatan produksi juga semakin meningkat.

Peningkatan berat kering gabah juga disebabkan oleh terjadinya peningkatan kandungan P-tersedia tanah. Hingga minggu ke 8 penggenangan jumlah peningkatan kadar P-tersedia tanah untuk semua perlakuan dapat mencapai 17.72 - 20.51 ppm. Semakin besar P yang tersedia bagi tanaman, maka kemampuan tanaman untuk menghasilkan biji juga akan semakin meningkat. Hal ini dikarenakan unsur $\mathrm{P}$ mempunyai peranan penting dalam pembentukan biji dan buah..

Berat kering gabah tertinggi terdapat pada tanah dengan kandungan sisa asam humat pada takaran $600 \mathrm{ppm}$, yaitu sebesar 24.50 g. Hal ini dikarenakan pada takaran tersebut kandungan $\mathrm{Fe}^{+2}$ tanah paling rendah. Kelarutan $\mathrm{Fe}$ hanya berkisar antara 68.56 - $107.70 \mathrm{ppm}$ dan kandungan Ptersedia mencapai 11.37-12.47 ppm hingga minggu ke 8 penggenangan.

Berat kering gabah pada penanaman kedua ini lebih tinggi bila dibandingkan dengan berat kering gabah total pada penanaman pertama. Berat kering gabah total pada penanaman kedua ini mencapai 10.00-24.50 g, sedangkan berat kering gabah total pada penanaman pertama hanya 8.20-15.90g (Herviyanti, 2007). Hal ini dikarenakan keracunan $\mathrm{Fe}^{2+}$ terhadap tanaman pada penamanan kedua semakin berkurang, sehingga kemampuan tanaman dalam menyerap hara $\mathrm{P}$ semakin meningkat dan pertumbuhan tanaman semakin baik.

Berat 1000 butir gabah (g) 
Penggenangan selang seling pada berat 1000 butir lebih berat bila dibandingkan dengan berat 1000 butir gabah pada penggenangan terus menerus. Dengan penggenangan selang seling berat 1000 butir gabah dapat mencapai $15.08 \mathrm{~g}$, sedangkan untuk penggenangan terus menerus hanya 11.50 g. Hal ini membuktikan bahwa dengan penggenangan selang seling tanaman dapat tumbuh dengan baik, dimana keracunan tanaman terhadap kelarutan $\mathrm{Fe}$ dapat berkurang. Kandungan $\mathrm{Fe}^{+2}$ tanah yang lebih rendah (36.08-114.23 ppm) pada penggenangan selang seling dapat meningkatkan ketersediaan hara bagi tanaman terutama kandungan hara $\mathrm{P}$ yang sangat penting bagi pembentukan buah.

Peningkatan berat 1000 butir gabah dengan penggenangan selang seling $3.58 \mathrm{~g}$ lebih berat bila dibandingkan dengan berat 1000 butir gabah pada penggenangan terus menerus. Hal ini membuktikan bahwa dengan penggenangan selang seling penyerapan hara oleh akar tanaman dapat berlangsung dengan baik, terutama penyerapan hara $\mathrm{P}$ yang penting dalam pembentukan biji. Hal ini karena pada penggenangan selang seling kelarutan $\mathrm{Fe}$ tanah telah tercuci, sehingga kemampuan tanaman dalam menyerap hara $\mathrm{P}$ meningkat terlihat dari serapan $\mathrm{P}$. Breemen dan Moorman (1978) melaporkan bahwa $\mathrm{Fe}^{+2}$ yang tinggi pada zona perakaran mempengaruhi pertumbuhan dan hasil tanaman. Agus, Hadimihardja, Hardjowigeno, Fagi dan Hartatik (2004 cit Herviyanti 2007) menambahkan bahwa kadar $\mathrm{Fe}$ yang melebihi batas kritis keracunan tanaman terhadap $\mathrm{Fe}$ dapat menurunkan serapan hara $\mathrm{P}$ oleh tanaman yang akan menurunkan produksi tanaman.

Berat gabah tertinggi terdapat pada perlakuan sisa asam humat pada takaran 600 ppm (1200 kg/ha) yaitu $19.67 \mathrm{~g}$ yang dikombinasikan dengan penggenangan selang seling. Dibandingkan dengan penanaman pertama, berat 1000 butir pada penanaman kedua relatif sama, namun bila dibanding dengan deskripsi tanaman padi varietas Cisokan, berat gabah masih rendah. Berat gabah pada deskripsi tersebut yaitu 22 g. Hal ini dikarenakan tanaman masih keracunan $\mathrm{Fe}^{+2}$ sehingga tanaman belum dapat tumbuh dengan baik.

\section{Berat kering jerami tanaman padi (g)}

Berat kering jerami tanaman padi meningkat seiring meningkatnya sisa dari asam humat yang telah diberikan pada penanaman pertama. Pengelolaan air juga berpengaruh terhadap berat kering jerami bahwa penggenangan selang seling mempunyai berat kering jerami yang lebih berat yaitu $4 \mathrm{~g}$ dari pada penggenangan terus menerus.

Penggenangan selang seling dapat meningkatkan berat kering jerami padi dari $9.24 \mathrm{~g}$ (tanpa pemberian asam humat) menjadi $19.86 \mathrm{~g}$ pada sisa asam humat dengan peningkatan takaran menjadi 600 ppm. Hal ini karena pada penggenangan selang seling dengan sisa asam humat dapat memperbaiki kesuburan tanah, terutama dalam mengurangi keracunan $\mathrm{Fe}$ tanaman dan meningkatan ketersediaan hara terutama hara $P$ yang sangat penting bagi pertumbuhan tanaman.

\section{Kadar P tanaman (\%)}

Kadar P tanaman dengan pengelolaan air akibat sisa asam humat sudah berada diatas titik kritis, yaitu >0,1\% P (Sanchez, 1993). Hal ini karena kadar $P$ tanah sudah berada pada kriteria sedang dan penyerapan hara $\mathrm{P}$ telah mulai optimal seiring dengan menurunnya tingkat keracunan $\mathrm{Fe}^{2+}$ terhadap tanaman.

Kadar $\mathrm{P}$ tanaman akibat sisa asam humat untuk kedua perlakuan penggenangan lebih tinggi dibandingkan dengan kadar $\mathrm{P}$ tanaman tanpa pemberian asam humat. Pada tanah dengan sisa asam humat kadar $\mathrm{P}$ tanaman berkisar antara $0,35-0,65 \%$, sedangkan pada tanah tanpa asam humat hanya $0,27-0,33 \%$. Hal ini karena sisa asam humat dapat menurunkan kelarutan $\mathrm{Fe}$ tanaman, sehingga keracunan tanaman oleh kelarutan $\mathrm{Fe}$ yang dapat menghambat penyerapan hara oleh akar dapat berkurang. Hingga minggu ke 8 penggenangan peningkatan kelarutan $\mathrm{Fe}$ menurun seiring dengan meningkatnya takaran asam humat, yaitu berkisar antara $53.57-20.40 \mathrm{ppm}$. 
Kadar $\mathrm{P}$ tanaman tertinggi terdapat pada tanah dengan perlakuan selang seling akibat sisa asam humat dengan takaran 600 ppm, yaitu $0.65 \%$. Hal ini disebabkan oleh kelarutan $\mathrm{Fe}$ tanah pada perlakuan tersebut lebih kecil yaitu 20.40 ppm. Penggenangan selang seling dapat menurunkan kelarutan Fe melalui pencucian, sedangkan sisa asam humat dapat mengikat Fe terlarut sehingga interaksi antar kedua perlakuan ini sangat baik dalam menurunkan keracunan tanaman terhadap Fe.

Susilo (1991, dalam Herviyanti 2007) mengemukakan bahwa konsentrasi unsur $\mathrm{P}$ dalam larutan tanah umumnya sangat rendah, namun kadar $\mathrm{P}$ tersebut dapat ditingkatkan dengan cara meningkatkan dosis pupuk dan penambahan bahan organik kedalam tanah. Sisa asam humat yang ada didalam tanah dapat meningkatkan kadar $\mathrm{P}$ tanaman, dimana kadar $\mathrm{P}$ tertinggi terdapat pada perlakuan penggenangan selang seling dengan 600 ppm takaran asam humat. Hal ini berarti interaksi antara sisa asam humat dan pengelolaan air mampu menyediakan $\mathrm{P}$ bagi tanaman. Pada tanah dengan penggenangan selang seling terjadi pencucian $\mathrm{Fe}$ dan pengikatan $\mathrm{Fe}$ oleh sisa asam humat, sehingga $\mathrm{P}$ yang diikat oleh $\mathrm{Fe}$ dapat dilepaskan ke dalam larutan tanah dan menjadi tersedia bagi tanaman.

Kadar $\mathrm{P}$ tanaman pada penanaman kedua ini lebih tinggi bila dibandingkan dengan kadar $\mathrm{P}$ pada penanaman pertama. Kadar P tanaman pada penanaman pertama hanya berkisar antara $0.048-0.065 \%$ (Herviyanti, 2007), sedangkan kadar P tanaman pada penanaman kedua mencapai $0.27-0.65 \%$. Hal ini karena keracunan tanaman terhadap Fe pada penanaman kedua juga semakin berkurang. Kelarutan Fe yang berkisar antara 68.56 - 316.34 ppm pada penanaman kedua lebih rendah dari kelarutan Fe pada penanaman pertama yang mencapai 900 - 1000 ppm (Herviyanti, 2007).

\section{KESIMPULAN}

Efek sisa asam humat dan pengelolaan air ternyata masih mampu menurunkan peningkatan kelarutan $\mathrm{Fe}$ tanah sawah dari 95.00 ppm menjadi 53.57 ppm, dan meningkatkan serapan hara $\mathrm{P}$ tanaman yang berkisar antara $0.34-0.65 \%$ serta meningkatkan hasil tanaman padi menjadi $24.50 \mathrm{~g} /$ pot. Tanah dengan efek sisa asam humat pada takaran 600 ppm yang digenangi selang seling mampu menekan kelarutan Fe tanah sampai mendekati kadar yang tidak meracun, dengan kisaran kelarutan Fe tanah terendah antara 36.08 68.56 ppm.

Efek sisa asam humat mengurangi peningkatan kadar Fe tanah sawah bukaan baru berkisar antara 53.57 - 144.25 ppm untuk penggenangan terus menerus dan 20.40 - 23.36 ppm untuk penggenangan selang seling pada minggu ke 8 , dan meningkatkan serapan hara $\mathrm{P}$ serta produksi tanaman.

\section{Ucapan Terimakasih}

Penghargaan dan ucapan terimakasih yang sebesar-besarnya disampaikan pada Proyek SP4 Jurusan tanah yang telah membantu dalam pendanaan untuk kelancaran penelitian ini. Selanjutnya ucapan terimakasih juga disampaikan pada Ibuk Ir. Ruhaimah, MS dan Ibuk Dr. Ir. Herviyanti, MS yang telah membantu terlaksananya penelitian ini baik moril dan meteril.

\section{DAFTAR PUSTAKA}

Ahmad, F. 1990. Ameliorasi sawah bukaan baru dengan pupuk alam organik Dalam Prosiding Pengelolaan Sawah Bukaan Baru Menunjang Swasembada Pangan dan Program Transmigrasi di Padang. Fakultas Pertanian Universitas Ekasakti Padang dan Balitan sukarami Solok. Hal 193-197.

Burbey, Z. Hamzah, dan Z. Zaini. 1990. Pengendalian Keracunan Besi di Lahan Masam. Dalam Prosiding Pengelolaan Sawah Bukaan Baru Menunjang Swasembada Pangan dan Program Transmigrasi di Padang. Fakultas Pertanian 
Universitas Eka Sakti dan Balitan Sukarami Solok. Hal 367-385.

Breemen, N.V. dan F. R. Moorman. 1978. Iron-toxic soils. In Soils and Rice. The International Rice Research Institute. Los Banos Philipines. Halaman 781-800.

Departemen Pemukiman dan Prasarana Wilayah Sumatera Barat. 2001. Laporan Survai lapisan tanah atas dan tata guna lahan sekarang pada daerah irigasi Batang Hari Paket LCB - 6 (Lot - 4). Padang. IV : 322.

Herviyanti, Prasetyo, T. B, Alif, A dan Agita Tjandra. 2005. Upaya pengendalian keracunan Besi $(\mathrm{Fe})$ dengan asam humat dan pengelolaan air untuk meningkatkan Produktivitas tanah sawah bukaan baru. Laporan Penelitian Hibah Bersaing Tahun I. 47 hal.

Herviyanti. 2007. Upaya pengendalian keracunan besi $(\mathrm{Fe})$ dengan asam humat dan pengelolaan air untuk meningkatkan produktifitas tanah sawah bukaan baru. Disertasi PascasarjanaUniversitas Andalas. Padang. 169 halaman.

Ismunadji, Sabe. 1988. Pengaruh Pospat dan Hara Lain Terhadap Keracunan Besi pada Padi Sawah. Balai Penelitian Tanaman Pangan Bogor. Hal 231-269.

Kurniawan, C. dan Rima, P. 1997. Pemanfaatan fraksi humat asal jerami padi untuk perbaikan dan peningkatan produktivitas tanah Podzolik. Fakultas Pertanian Universitas Sriwijaya. Indralaya. Hal 16-17.

Noor, M. 1996. Padi Lahan Marginal. Penebar Swadaya. Jakarta. 213 hal.

$\begin{array}{llll}\text { Ponnamperuma F. } & \text { N. } & 1978 .\end{array}$ Electrochemical changes in submerged soils and growth of rice. In Soils and Rice. The International Rice Institute. Los Banos, Laguna Philippines. Hal 421-437.

Prasetyo,H.B. Adiningsih,S.J. Subagyono,K. Simanungkalit,M.D.R, 2004. Mineralogi, Kimia, Fisika, dan Biologi Lahan Sawah dalam Tanah Sawah dan Teknologi Pengelolaannya. Badan Penelitian dan Pengembangan Pertanian. Departemen Pertanian. Hal 29-56.

Sanchez, A. P. 1993. Sifat dan ciri pengelolaan tanah tropika. Terjemahan dari Amir Hamzah. Jilid 2. Penerbit ITB. Bandung. Hal 91-92.

Sari, D. A. 2005. Pemberian asam humat dan polisakarida dalam mengurangi kelarutan besi $(\mathrm{Fe})$ tanah sawah bukaan baru di Sitiung Sumatera Barat. Skripsi Sarjana Pertanian Universitas Andalas Padang. 95 halaman.

Satari, G. Nurpilihan, dan Y. Sumarni. 1990. Masalah keracunan besi dan keragaan tanaman padi pada agroekosistem sawah. Dalam Prosiding Pengelolaan Sawah Bukaan Baru Menunjang Swasembada Pangan dan Program Transmigrasi di Padang. Fakultas Pertanian Universitas Eka Sakti Padang dan Balitan Sukarami Solok. Hal 329-341.

Susanto, R. 2002. Penerapan pertanian organik. Kanisius. Yogyakarta. 219 hal.

Taher, A. 1990. Perpadian dunia, transmigrasi dan pengelolaan sawah bukaan baru di Indonesia. Dalam Prosiding Pengelolaan Sawah Bukaan Baru Menunjang Swasembada Pangan dan Program Transmigrasi di Padang. Fakultas Pertanian. Universitas Ekasakti 
Padang dan Balitan Sukarami Solok. Hal 4-8.

Yardha dan A.Yusuf. 1993. Toleransi tiga varietas padi sawah terhadap keracunan besi. Buletin Pertanian, volume 12 No.3. Hal 23-25.
Dalam Prosiding Pengelolaan Sawah bukaan Baru Menunjang Swasembada Pangan dan Program Transmigrasi di Padang, Fakultas Pertanian Universitas Eka Sakti dan Balitan sukarami solok. Hal 237-263.

Yusuf, A, S. Djakamihardja, G. Satari dan S.D.Sutami. 1990. Pengaruh $\mathrm{pH}$ dan Eh Tanah terhadap kelarutan $\mathrm{Fe}$, Al dan Mn pada lahan sawah bukaan baru jenis Oxisol, Sitiung. 